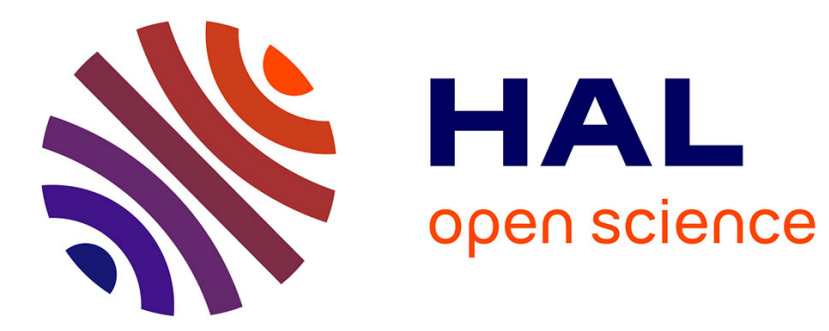

\title{
Reanimating places: a geography of rhythms
}

Derek Mccormack

\section{To cite this version:}

Derek Mccormack. Reanimating places: a geography of rhythms. cultural geographies, 2006, 13 (2), pp.307-308. 10.1177/147447400601300210 . hal-00571990

\section{HAL Id: hal-00571990 https://hal.science/hal-00571990}

Submitted on 1 Mar 2011

HAL is a multi-disciplinary open access archive for the deposit and dissemination of scientific research documents, whether they are published or not. The documents may come from teaching and research institutions in France or abroad, or from public or private research centers.
L'archive ouverte pluridisciplinaire HAL, est destinée au dépôt et à la diffusion de documents scientifiques de niveau recherche, publiés ou non, émanant des établissements d'enseignement et de recherche français ou étrangers, des laboratoires publics ou privés. 
Reanimating places: a geography of rhythms. Edited by Tom Mels. Aldershot: Ashgate. 2004. 278 pp. $£ 49.95$ cloth. ISBN 0754641872.

For geographers, rhythm is one of the most seductive and elusive of concepts. And, as Tom Mels's expansive introductory essay to this collection demonstrates, it is possible to trace the 'lineage of a geography of rhythms' through various theoretical and empirical trajectories. The content and tone of this volume is, however, dominated by one particular trajectory - humanistic geography. As such, in addition to being a welcome contribution to wider geographical engagements with temporality, for this reader the book served as useful reminder of intellectual traditions that have sometimes been under-acknowledged within culturally inflected human geography, and more particularly in work about rhythm. A more specific touchstone for the contributions to this volume is Anne Buttimer's writing in the late 1970s about the rhythms of time-space. As Mels suggests, while Buttimer's interest in rhythm emerges from a particular concern with the phenomenological and existential elements of everyday life, this interest resonates in different ways with aspects of time-geography, Marxist geography, and with the 'rhythmanalysis' of Bachelard and Lefebvre.

Buttimer's humanistic engagement with the rhythms of place is read by Mels as an enlivening gesture - an effort to animate space in the context of an increasingly 'reified world of positivist science and technocracy' (p. 8). Despite the diversity of their subjects, each of the chapters in this book can be read as an attempt to foreground the lived temporality of space and to disrupt the 'danse macabre of abstract time-space' (p. 34). Some chapters have an immediately familiar humanistic tone, most notably those by Tuan, Ley and Bunkše, each of which engages with the rhythms of place, home and displacement. Unsurprisingly, there are also discussions focusing on the possibilities and problems of attuning with a degree of authenticity to the multiple rhythms of place and landscape (Bunkše, Johnson, O'Reilly, Relph, Sack). Other authors work to draw out the literal and metaphoric choreography of the connections and contradictions between the lived rhythms of place and wider social, political and economic processes (Åquist, Clark, Godlewska, Olwig, Relph, Seamon). And at times this choreography is affectively amplified by the rhythms of an enactive style of writing (Olsson).

Admittedly, the diversity of the collection means that the connections between some contributions and the central thematic of rhythm is not always entirely clear, although presumably this reflects the editor's desire to engage the multiple rhythms of the discipline and, indeed, to avoid disciplining the meaning of rhythm itself. More importantly, for this reader - and perhaps others - the humanistic tone of the book prompted a series of important questions. Does abstraction always work against the apprehensions of lived, animate space? Is rhythm always affirmatively animating? Are such animations distinctively human? And what kinds of styles of work might apprehend more (and less) than human rhythms? While the contribu- 
tions here hint at possible and interesting answers, they are - perhaps inevitably circumscribed by the tradition from which the collection emerges.

School of Geography, University of Southampton

DeReK McCormack

The globalization of sexuality. By Jon Binnie. London: Sage. 2004.167 pp. $£ 60$ cloth; $£ 19.99$ paper. ISBN 0761959351 cloth; $076195936 \mathrm{X}$ paper.

In The globalization of sexuality, Jon Binnie cogently demonstrates how the cultural interpenetrates with the economic in processes of 'queer globalization', countering both the economic determinism of much globalization research (where the globalization of culture is posited as a consequence of transnational economic flows) and the largely anti-materialist bias of queer theory and gay/lesbian studies (which often marginalize questions of class and economics). He also takes issue with researchers of sexuality, particularly Altman, who overemphasize a political economic basis to queer globalization, and argue that so-called 'global gay' culture is a consumption-based byproduct of the US domination of international economic linkages. Instead, Binnie explores the mutual relationship between (homo)sexual desire and political economy manifested on interconnected local, national and global scales.

Several key themes emerge. Prominent among them is a consistent critique of the class bias implicit in constructions of gay/lesbian/queer (GLQ) identities: the cost of participating in the consumer spaces of commercial 'gay villages', or in the events which symbolize 'global gay' (e.g. the Gay Games, the Sydney Gay and Lesbian Mardi Gras), means that GLQ identity is a middle-to-upper-class identity. This distances working-class queers from a claim to GLQ identity, and has further implications in the context of globalization. Binnie demonstrates that global citizenship, and the associated ability to advance GLQ rights internationally, is reserved for the economically active and powerful. The development of GLQ rights in an international context consequently reflects middle-to-upper-class values, further marginalizing working-class queers. This raises the related issues of authenticity and inclusion/exclusion: who has the right to belong to, and participate in, the 'queer community'? In a globalized world, authenticity seems to be based on the ability to pay and to adhere to middle-to-upper-class values of moral respectability. Binnie also critiques the ethnocentrism of GLQ studies - not only the US bias in the production of knowledge, but also the emergence of a 'new racism' where nation-states' levels of development are measured by their differing attitude towards homosexuality, permitting some nations to claim a moral high ground in an international context based on the extension of rights to queers. Binnie suggests that in this context the internationalization of GLQ activism may be part of a neocolonial 'Western' civilizing mission. A related theme is the invisibility of national identity in questions of queer globalization. Binnie is critical of those who claim that national cultural differences are erased by transnational connectivity and 'global gay' consumer culture. Although gay bars may look similar in global cities, cultural differences mean that queers use these spaces in different ways. He is thus sensitive 